\title{
Greener Cleaner: Liquid-Phase Adsorption of Dye Using Macroalgae Based Biosorbent Materials
}

\author{
Mohamed Sulyman*, Sadig Al-Marog, and Khaled Al-Azabi \\ Department of Chemistry, Tajoura Nuclear Research Center, Libya \\ *Corresponding Author: Mohamed Sulyman, Department of Chemistry, Tajoura Nuclear Research Center, Libya. \\ E-mail: mohsuly1@pg.edu.pl
}

Received: May 13, 2019; Published: June 06, 2019

DOI: 10.31080/ASAG.2019.03.0513

\begin{abstract}
Dyes are considered one of the most dangerous pollutants. Due to its toxicity to many life forms. Dying-wastewater also has a great impact on the ecosystem by putting the marine lives at high level of risk. In this study, treated macroalgae with potassium carbonate $\left(\mathrm{K}_{2} \mathrm{CO}_{3}\right)$ has been used as a low cost and eco-friendly adsorbent materials for the removal of Crystal violet (CV) dye from water using batch mode system. The Influence of various important parameters such as contact time, initial dye concentrations, solution $\mathrm{pH}$, amount of biomass, and solution temperature were investigated. The UV-visible spectrophotometer was applied to analyze the remaining dye concentrations in the treated solution. According to the data derived, Langmuir isotherm model was best fit the experimental results. The equilibrium adsorption time was reached within 90 min. Maximum adsorption capacity for CV adsorption onto macroalgae was found to be $38.4 \mathrm{mg} / \mathrm{g}$. The kinetics analysis revealed that the pseudo-second-order model was a better fit for the experimental data than the pseudo-first order. The thermodynamic study demonstrates the spontaneous and endothermic nature of adsorption system. Finally, the presented study observed that macro alga-based biomass could be utilized in the removal of basic dyes from wastewater with high removal efficiency up to $98 \%$. Also, algae biomass could be more economic and effective biosorbent for the control of dyes from industrial liquid wastes.
\end{abstract}

Keywords: Adsorption; Algae; Batch mode; Crystal violet; Equilibrium; Isotherm; Kinetic

\section{Introduction}

Water is used everywhere and plays such a vital role in our lives, but its supply is increasingly threatened by an increase in the generation of waste effluents [1]. Managing waste and preserving the quality of water are now two of the important tasks of human life [2]. Dyes are organic pollutants that pose a particular danger to the environment. Synthetic dyes (SD) are widely used in many areas of advanced technology such as dyestuff, paper, printing, carpet, plastic, food and cosmetic, paint manufacture and textiles to provide colour to their products $[3,4]$, and as additives in petroleum products [5]. The textile industry uses large volumes of water in its manufacturing processes. As a result, they generate large amounts of colored wastewater [6]. It is reported that in the dyeing section of a textile industry, about $1 \mathrm{~m} 3$ of water is used for every ton clothes processed [5]. Thousand different types of dyes and pigments are available commercially and around $10-15 \%$ of such dyes are lost in the effluent during manufacturing and processing operations $[5,7,8]$. Chemically, synthetic dyes possess aromatic structures that are biologically non-degradable and whose efflu- ents are difficult to treat $[5,9,10]$. A particularly difficult task for the wastewater treatment plants of textile industries is the elimination of the color of these compounds, as dyes and pigments are resistant to biodegradation. They typically remain in the environment for a long period of time. For example, the hydrolyzed dye reactive blue 19 has a half-life of around 46 years at room temperature and a pH of 7 [7]. A number of treatment techniques are available with different degree of sources to control and reduce pollution of water [11]. These technologies including chemical precipitation, ion exchange, membrane separation, electrochemical treatment, oxidation and coagulation/flocculation [12]. Nowadays, adsorption process is a very cost-effective and efficient treatment approach for the removal of pollutants from water and wastewater in comparison with the conventional methods [12]. In addition, adsorption process has offered flexibility in operation and design, and could be produce high-quality treated effluent [12]. Algae is a diverse group of photosynthetic organisms ranging from unicellular (microalgae) to multicellular (macroalgae) forms inhabiting freshwater and marine environments [13]. 
In recent years, there has been a growing interest in utilizing seaweed such as macroalgae to remove various water pollutants including heavy metals and dyes [11,13,14]. More recently, the possible application of algae biomass in nuclear waste management has been explored [14]. Because the structures of these biochemical substances are associated with a various functional group, such as carboxyl, hydroxyl, amine, carbonyl, and sulfate, which participated in the adsorption system $[13,14,15]$. However, there are several studies being conducted in this trend, particularly in the adsorption of heavy metals from liquid media [13]. Because algae biomass is abundance, economically attractive, and environmentally friendly adsorbents [14]. In the current study macro algaebased biomass has been utilized as a green and potential low-cost adsorbent for the adsorption of crystal violet from aqueous phase. Studies of equilibrium, isotherm, kinetics and thermodynamics are the main purposes of the study. This study indicates that algae biomass could be successfully applied at industrial effluents as adsorbent materials without or with a little bit of modification. Figure 1 shows the application of algae biomass.

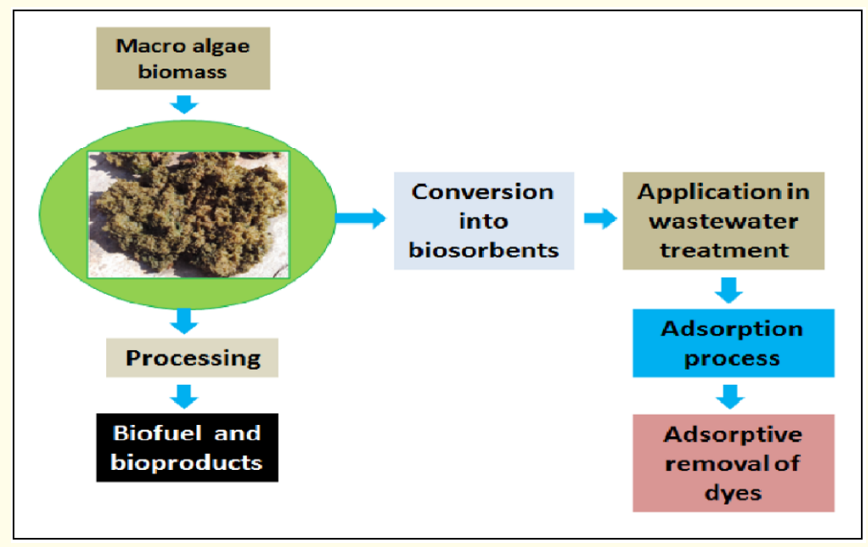

Figure 1: Applications of macro algae based biomass.

\section{Experimental work \\ Materials}

In this study, macro algae has been selected as a potential low cost biosorbent material for the removal of basic dye from aqueous phase. The algae biomass was obtained from the saltwater ponds on farms in Libya. The raw materials were collected from the site and put into glass container and immediately transported to the laboratory. Then, the material was washed completely with water to remove salt, dust, and other impurities and undesirable materials. After that, the biomass was chemically treated by being soaked in potassium carbonate $\left(\mathrm{K}_{2} \mathrm{CO}_{3}\right)$ solution and stirred in a water bath at $65^{\circ} \mathrm{C}$ for $4 \mathrm{hr}$. It was subsequently washed with distilled water and pure acetone respectively, and oven-dried at $105^{\circ} \mathrm{C}$. Finally, the dried biomass was crushed and sieved and stored in plastic bags for further use.
Crystal violet (CV) (molecular weight $=408 \mathrm{~g} / \mathrm{mol} ; \lambda \max$ $=584 \mathrm{~nm}\}$, a cationic dye purchased from B.D.H Chemicals, Ltd., England was chosen as the model adsorbate. Working solutions were prepared from an aqueous stock solution $(1000 \mathrm{mg} / \mathrm{l})$ by diluting the dye stock solution with distilled water to give the needed initial concentrations ranging from 10 to $100 \mathrm{mg} / \mathrm{L}$ by using formula (1) [16]. To estimate the bulk density of dried biomass, a glass cylinder $25 \mathrm{ml}$ was filled to a specified volume with powdered biomass and dried in an oven at $70^{\circ} \mathrm{C}$ for $24 \mathrm{hr}$. The cylinder was tapped for few minutes to compact the material and the bulk density estimated and presented as $\mathrm{g} / \mathrm{ml}$ using formula (2) $[16,17]$, and was found to be $0.41 \mathrm{~g} / \mathrm{ml}$.
$\mathrm{C} 1 \mathrm{~V} 1=\mathrm{C} 2 \mathrm{~V} 2$
$\mathrm{D}=\mathrm{W} / \mathrm{V}$

where $\mathrm{D}$ is the bulk density of biomass $(\mathrm{g} / \mathrm{ml}), \mathrm{W}$ is the weight of dry biomass $(\mathrm{g})$, and $\mathrm{V}$ is the final volume $(\mathrm{ml})$

\section{Batch adsorption process}

Adsorption experiments were carried out in $250 \mathrm{ml}$ beakers containing fixed amount of biomass $(0.3 \mathrm{~g})$ with $100 \mathrm{ml}$ of dye solution $(70 \mathrm{mg} / \mathrm{l})$. The mixture was stirred at a temperature of $50 \mathrm{oC}$, $\mathrm{pH}$ 8, for 30 min using normal mixer at stirring speed of 800rpm. The influence of different factors affecting adsorption process such as contact time, $\mathrm{pH}$, adsorbent mass, initial dye concentrations, and temperature were investigated. The final concentration of dye was analyzed by UV-vis spectrophotometer after separation of solid phase from the mixture by filter paper. The adsorption capacity (qe) was calculated from the following Equation [16]:

$q_{e}=\left(C_{i}-C_{e}\right) V / M$

where $\mathrm{C}_{\mathrm{i}}$ and $\mathrm{C}_{\mathrm{e}}$ are the initial and equilibrium concentrations of dye (mg/l), respectively, $\mathrm{V}$ is the total volume of dye solution (l), and $\mathrm{M}$ is the mass of the adsorbent used (g). While, the percentage removal of CV was determined according to the equation (4) [16]. Matrix of the experimental work including, range and levels of independent process variables are given in Table 1.

$\%$ Removal $=\left(\mathrm{C}_{\mathrm{i}}-\mathrm{C}_{\mathrm{e}} / \mathrm{C}_{\mathrm{i}}\right) \times 100$

\section{Results and Discussion}

\section{Affecting parameters on the adsorption system} Influence of $\mathrm{pH}$

The $\mathrm{pH}$ factor is very important and controlling parameter in the adsorption process for the treatment of water pollution [16]. The experiments were carried out as follow: $100 \mathrm{ml}$ of $70 \mathrm{mg} / \mathrm{l} \mathrm{CV}$ dye solution, were stirred with $0.25 \mathrm{~g}$ of solid phase "biomass adsorbent" using $250 \mathrm{ml}$ beakers at solution $\mathrm{pH}$ from 3 to 9 through a batch mode system at temperature of $50^{\circ} \mathrm{C}$ for $60 \mathrm{~min}$. Stirring 


\begin{tabular}{|l|c|c|c|c|c|}
\hline \multirow{2}{*}{$\begin{array}{c}\text { Influential } \\
\text { Factors }\end{array}$} & $\begin{array}{c}\text { Adsorbent } \\
\text { dosage }\end{array}$ & $\begin{array}{c}\text { Initial } \\
\text { conc. }\end{array}$ & pH & $\begin{array}{c}\text { Contact } \\
\text { time }\end{array}$ & $\begin{array}{c}\text { Temper- } \\
\text { ature }\end{array}$ \\
\cline { 2 - 6 } pH & 0.25 & 70 & $3-9$ & 60 & 323 \\
\hline $\begin{array}{l}\text { Adsorbent } \\
\text { mass(g) }\end{array}$ & $0.15-0.5$ & 70 & 6.5 & 60 & 323 \\
\hline $\begin{array}{l}\text { Concentra- } \\
\text { tion (mg/l) }\end{array}$ & 0.25 & $30-100$ & 6.5 & 60 & 323 \\
\hline $\begin{array}{l}\text { Tempera- } \\
\text { ture (K) }\end{array}$ & 0.25 & 70 & 6.5 & 60 & 323 \\
\hline $\begin{array}{l}\text { Contact time } \\
\text { (min) }\end{array}$ & 0.25 & 70 & 6.5 & $10-120$ & $293-328$ \\
\hline
\end{tabular}

Table 1: The influence of factors on the rate of dye adsorption by macroalgae.

speed was fixed at $800 \mathrm{rpm}$ for the whole adsorption process. The $\mathrm{pH}$ values of the solution were adjusted with $1 \mathrm{M}$ of $\mathrm{HCl}$ for the acid media and $1 \mathrm{M}$ of $\mathrm{NaOH}$ solution for the basic media respectively. Figure 2 shows the effect of $\mathrm{pH}$ on the adsorption efficiency for $\mathrm{CV}$ dye onto biomass. The results show that the percentage removal of $\mathrm{CV}$ dye rapidly increased with increasing $\mathrm{pH}$ values until reaches maximum at $\mathrm{pH}$ (6.5). A similar behavior was observed for the removal of basic dye from aqueous solution by orange peel powder [16], coffee waste [18], wasted Oolong tea [19], Gmelina Arborea biomass [20], olive-waste cake [21], marine macroalgae [22].This trend may be described to electrostatic interaction between cationic dye (CV) and the negative surface of adsorbent. Lower removal of $\mathrm{CV}$ dye at the acid media may be due to the presence of excess $\mathrm{H}+$ ions that complete with the basic dye for adsorption site [16]. On the other hand, as the $\mathrm{pH}$ value increased, the number of negatively charged surface sites on the biomass adsorbent increased, thus enhancing the removal efficiency of CV dye from aqueous solution. The maximum percentage removal $\mathrm{CV}$ dye was reached at $\mathrm{pH} 6.5$ and found to be $98 \%$.

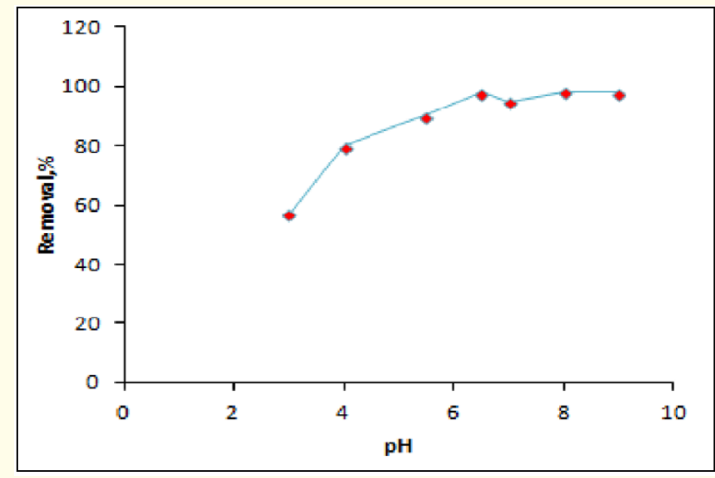

Figure 2: Infuece of pH on the removal of CV dye by macroalgae biomass.
Influence of adsorbent mass

The effect of adsorbent dose was performed by contacting different amounts of biomass in the range of $(0.15 \mathrm{~g}-0.5 \mathrm{~g})$ using 100 $\mathrm{ml}$ of $70 \mathrm{mg} / \mathrm{l}$ of $\mathrm{CV}$ dye solution at $\mathrm{pH}$ of 6.5 , reaction temperature of $50 \mathrm{oC}$, at a fixed mixing speed of 800rpm for $60 \mathrm{~min}$. Figure 3 shows the relation between the adsorption efficiency for $\mathrm{CV}$ removal and the adsorbent mass. From the figure it can be observed that with increase in adsorbent mass from 0.15 to $0.4 \mathrm{~g}$ the percentage removal of CV dye rapidly increased from $86 \%$ to $97.7 \%$. The adsorption equilibrium of dye was reached at adsorbent mass of $0.4 \mathrm{~g}$, and there is no change in the percentage removal of dye from 0.4 to $0.5 \mathrm{~g}$ of adsorbent was observed. In other site, the adsorption capacity was decreased from $40.13 \mathrm{mg} / \mathrm{g}$ to $13.66 \mathrm{mg} / \mathrm{g}$ as the adsorbent mass increasing from 0.15 to $0.5 \mathrm{~g}$. This behavior can be explained as a result of overlapping or aggregation of adsorption sites resulting in a decrease in the total adsorption surface area available to the dye and an increase in the diffusion path length [23]. However, $0.25 \mathrm{~g}$ was selected as optimum value of the adsorbent mass and has been used for the next stages. Similar trend for the influence of adsorbent amount on the adsorption efficiency for basic dyes was observed and reported in previous studies for other types of low-cost adsorbents [15-23].

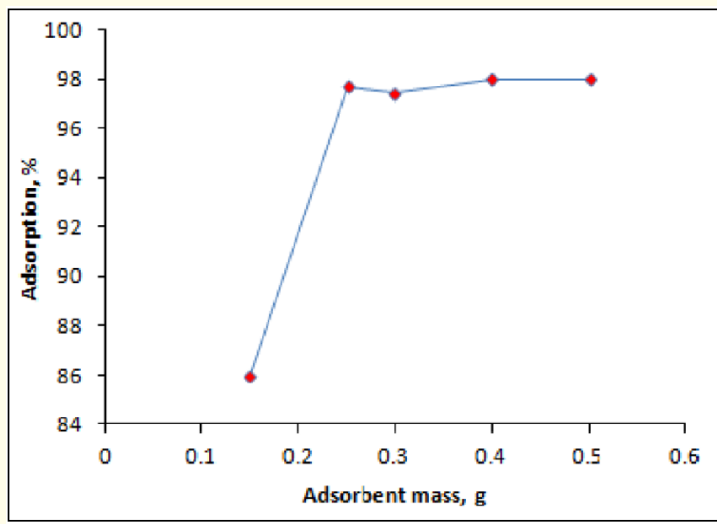

Figure 3: Relationship between adsorbent mass and removal of dye.

Infuence of initial dye concentration

To understand the infuence of initial dye concentration on the removal efficiency, a series of different concentrations for the removal of dye were performed at $\mathrm{pH}$ of 6.5 , solution temperature of $50 \mathrm{oC}$, adsorbent dose $0.25 \mathrm{~g}$, adsorption time of $60 \mathrm{~min}$, using $100 \mathrm{ml}$ of working solution and fixed agitaion speed at $800 \mathrm{rpm}$. The experimental result is shown in figure 4. In general, the adsorp- 
tion efficiency decreases with increase in the initial concentration of dye, whereas the adsorption capacity increases with the initial concentration increase [18]. From the figure can be seen that the adsorption capacity for CV by macroalgae has been increased from $11.88 \mathrm{mg} / \mathrm{g}$ to $30.8 \mathrm{mg} / \mathrm{g}$ with increasing the initial concentration of CV dye from $30 \mathrm{mg} / \mathrm{l}$ to $100 \mathrm{mg} / \mathrm{l}$, and then reached equilibrium. This is due to saturation of active sites on the adsorbent surface and exuthoin point takes place. This is agreement with several literatures that used low cost adsorbents for the removal of basic dyes from aqueous solution [16-22].

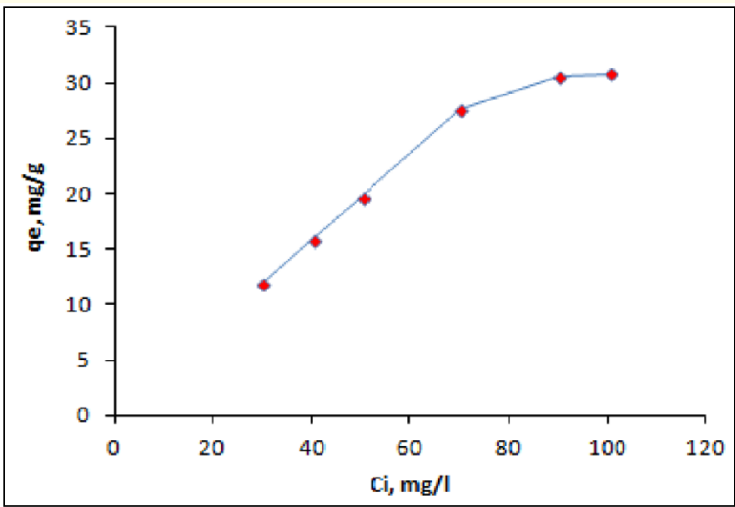

Figure 4: Influence of initial concentration on the adsorption capacity of CV.

\section{Infuenc of adsorption time}

The effect of adsorption time for the removal of $\mathrm{CV}$ from its aqueous solution was investagited. The experiments was carried out by contacting $100 \mathrm{ml}$ of $70 \mathrm{mg} / \mathrm{l}$ of CV initial dye concentration with $0.25 \mathrm{~g}$ of biomass at solution temperature of $50^{\circ} \mathrm{C}$, agitation speed of $800 \mathrm{rpm}$, and pH 6.5 using $250 \mathrm{ml}$ beakers, over time periods ranging from 10 to $120 \mathrm{~min}$. The remaining concentration of $\mathrm{CV}$ dye as function of contact time is shown in figure 5 . It can be concluded that the remaining concentration of dye in the solution after adsorption process was decreased from $28 \mathrm{mg} / \mathrm{l}$ to $1.12 \mathrm{mg} / \mathrm{l}$ with the increase of contact time from $10 \mathrm{~min}$ to $60 \mathrm{~min}$ and then reached equilibrium at contact time of $90 \mathrm{~min}$. The percentage removal of $\mathrm{CV}$ at equilibrium was found to be $98.4 \%$, while adsorption capacity for $\mathrm{CV}$ onto biomass was $27.6 \mathrm{mg} / \mathrm{g}$. This results is in trend with several works have been done previously by many researchers [16-21].

\section{Adsorption Isotherm}

The equilibruim adsorption isotherm is important element in the design of adsorption process [18]. In order to describe the

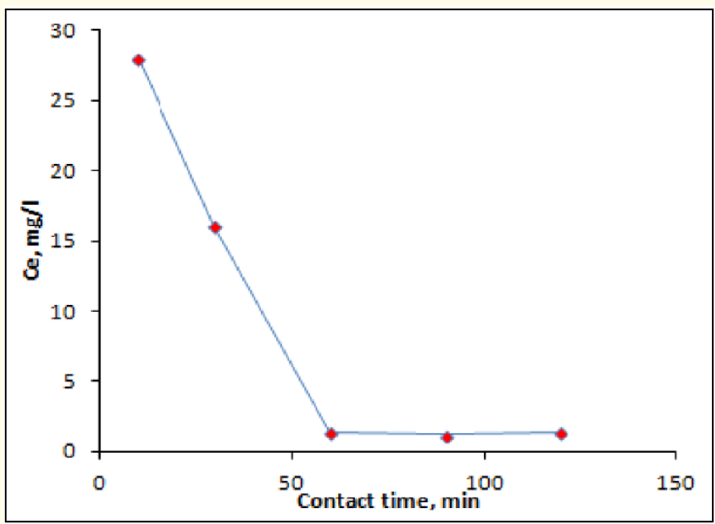

Figure 5: The effect of contact time on the adsorption of CV.

equilibrum between the solid and the liquid phases in the adsorption system, two isothem models (Langmuir and Ferundlich) are widely used for this purpose $[16,18]$.

Langmuir isotherm model is applied to describe the adsorption system where the occupancy occurs at a single adsorption site at an energetically homogeneous rage of adsorption sites [18]. The adsorption isothem studies were performed by varying the initial concentration of dye from 30 to $150 \mathrm{mg} / \mathrm{l}$, keeping all other conditions constant as follow: (pH 6.5, mixing speed $800 \mathrm{rpm}, 100 \mathrm{ml}$ of working solution, adsorbent mass of $0.25 \mathrm{~g}$ ). A plot of Ce/qe versus Ce, indicates a straight line of slope $\left(1 / \mathrm{q}_{\max }\right)$ and an intercept of $(1 / \mathrm{b}$ $\mathrm{q}_{\max }$ ), where Ce is the concentration of dye at equilibrium ( $\mathrm{mg} / \mathrm{l}$ ), $\mathrm{q}_{\mathrm{e}}$ is the amount of dye adsorbed at equilibrium ( $\mathrm{mg} / \mathrm{g}$ ), and $\mathrm{q}_{\max }$ is the maximum adsorption capacity for dye onto biomass (mg/g); $b$ is the Langmuir constant $(\mathrm{l} / \mathrm{mg})$. Equation 5 shows the Langmuir isotherm expressions that can be linearized to Eq. 6 [24].

$\mathrm{q}_{\mathrm{e}}=\left(\mathrm{q}_{\max } \mathrm{bCe}\right) /\left(1+\mathrm{b} \mathrm{C}_{\mathrm{e}}\right)$

$\mathrm{C}_{\mathrm{e}} / \mathrm{q}_{\mathrm{e}}=\left(1 / \mathrm{q}_{\max } \mathrm{b}\right)+\left(\mathrm{C}_{\mathrm{e}} / \mathrm{q}_{\max }\right)$

A plot of $\mathrm{C}_{\mathrm{e}} / \mathrm{q}_{\mathrm{e}}$ againts $\mathrm{Ce}$, gave a fitted curve, and the Langmuir constants were calculated regarding to figure 6 and data are presented in Table 2. The Langmuir isothem can also bee expressed in terms of a dimensionaless constant separation factor RL that is given by Eq. (7) [16,18].

$\mathrm{R}_{\mathrm{L}}=1 / 1+\mathrm{bC}_{\mathrm{e}}$

The values of the factor RL obtained are shown in figure 7 indicat that the adsorption process is favorable, since $(0<\mathrm{RL}<1)$. There were found to be in the range of $(0.048-0.01)$. Similar results were reported in previous works $[16,18,22]$. 


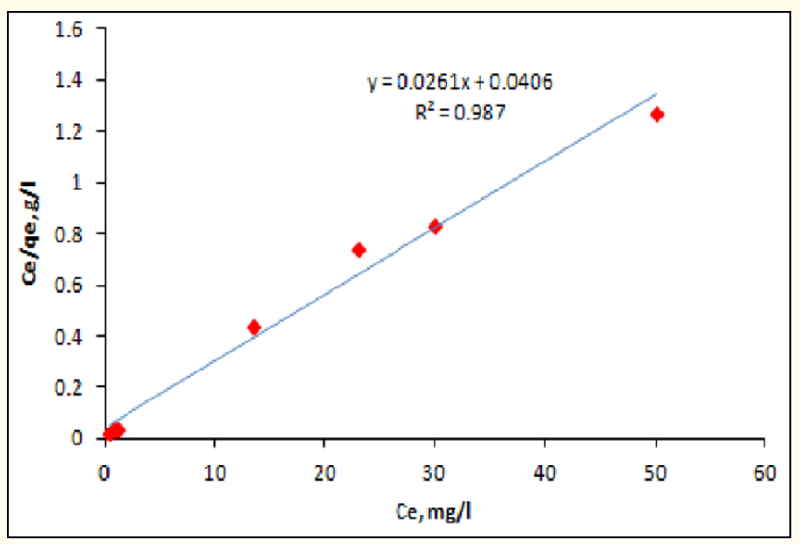

Figure 6: Langmuir isotherm plot for the adsorption of CV by macroalgae.

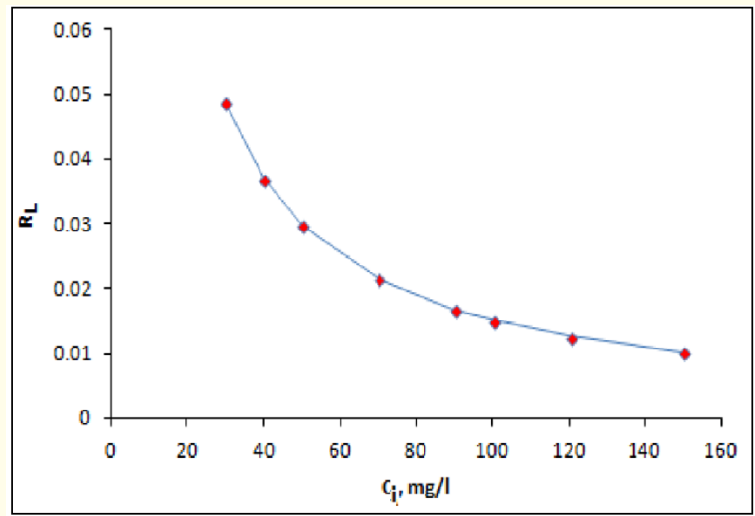

Figure 7: $\mathrm{R}_{\mathrm{L}}$ as function of initial CV dye concentration.

Freundlich isotherm model is mainly used to describe characteristics for the hetrogeneous surfac. The model assumes that adsorption takes place on a hetrogeneous surface, and can be used for non-ideal adsorption system [16]. The linear form of Freundlich isotherm is given as: [25].

$\ln \mathrm{q}_{\mathrm{e}}=1 / \mathrm{n} \ln \mathrm{C}_{\mathrm{e}}+\ln \mathrm{K}_{\mathrm{f}}$

where $\mathrm{q}_{e}$ is the amount of CV adsorbed onto biomass in equilibrium $(\mathrm{mg} / \mathrm{g}), \mathrm{C}_{\mathrm{e}}$ is the equilibrium dye solution concentration $(\mathrm{mg} / \mathrm{l}), \mathrm{K}_{\mathrm{f}}$ and $\mathrm{n}$ are the Freundlich equilibrium coefficients. A plot $\left(\ln q_{\mathrm{e}}\right.$ ) againts $\left(\ln \mathrm{C}_{\mathrm{e}}\right.$ ) gave lowere fitted curve than the Langmuir isotherm model. The values obtained of the Freundlich equilibrium coefficients $\mathrm{K}_{\mathrm{f}}$ and $\mathrm{n}$ from figure 8 are presented in Table 2 .

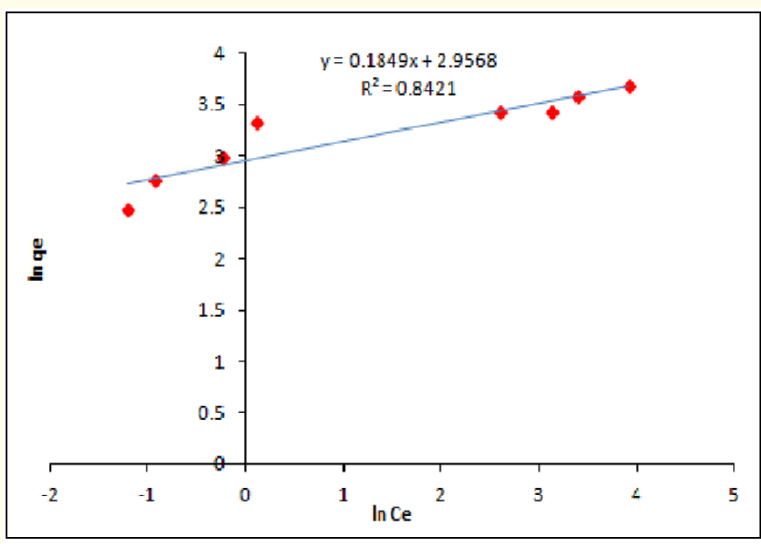

Figure 8: Freundlich isotherm plot for the adsorption of CV by macroalgae.

\begin{tabular}{|l|c|c|c|c|c|}
\hline \multicolumn{5}{|c|}{ Eqiulibrium isothem constants } \\
\hline \multicolumn{3}{|c|}{ Langmuir isotherm } & \multicolumn{3}{c|}{ Freundlich isotherm } \\
\hline $\mathrm{q}_{\max }$ & $\mathrm{b}$ & $\mathrm{R}^{2}$ & $\mathrm{~K}_{\mathrm{f}}$ & $\mathrm{n}$ & $\mathrm{R}^{2}$ \\
\hline 38.4 & 0.645 & 0.987 & 19.24 & 5.4 & 0.842 \\
\hline
\end{tabular}

Table 2: Equilibrium isotherm modeling of CV dye adsorption onto macroalgae biomass.

\section{Kintetic experiments}

There are two types of kinetice models including pseudo-first order [26], and pseudo-second order [27] which have been widely used to investigate the mechanism of bioadsorption and potential rate controlling steps such as mass transfer and chemical reaction process [28].The linear pseudo-first order Eq. is given as [18]:

$\log \left(\mathrm{q}_{\mathrm{e}}-\mathrm{q}_{\mathrm{t}}\right)=\left(\log \mathrm{q}_{\mathrm{e}}\right)-\left(\mathrm{k}_{1} / 2.303\right) \mathrm{t}$

where $\mathrm{q}_{\mathrm{e}}$ and $\mathrm{q}_{\mathrm{t}}$ are the amount of adsorbed CV dye onto biomass $(\mathrm{mg} / \mathrm{g})$ at equilibrium and at time $\mathrm{t}(\mathrm{min})$ respectively; $\mathrm{k}_{1}$ is the rate constant of pseudo-first-order model. The pseudo-second order equation is given as follows [18]:

$t / q_{t}=1 /\left(k_{2} q_{e}^{2}\right)+\left(1 / q_{e}\right) t$

where $\mathrm{k}_{2}(\mathrm{~g} / \mathrm{mg} \mathrm{min})$ is the rate constant of pseudo-secondorder equation.

Kinetic adsorption experiments were performed by stirring $100 \mathrm{ml}$ of a constant CV concentration with $0.25 \mathrm{mg}$ of adsorbent mass at $\mathrm{pH}$ value of 6.5 , stirring speed of $800 \mathrm{rpm}$, for $90 \mathrm{~min}$. The samples were then filtered by filter paper and the reminaing 
concentration of $\mathrm{CV}$ in the final solution was analyzed using UVvis spectrophotometer. The procedure was similar to that used by Aljeboree., et al. [29]. Figurs 9 and 10 showed the plots of pseudofirst order kinetic model and the pseudo-second-order model, respectively, for the removal of $\mathrm{CV}$ dye from aqueous solution onto macroalgae biomass. According to the data obtained, the results suggested that the pseudo-frist-order model is less suitable to describe the adsorption system combared to the pseudo-second-order model. The correlation coefficent of second-order-kinetic model (0.9963) is greater than for pseudo-first-order model (0.8452). This confirmed that the rate limiting step is chemisorption, involving valence forces through sharing or exchange of electrons between adsorbent and adsorbate [18]. The kinetic parameters of both models are reported in Table 3 . Works $[18,28,30]$ were also observed a similar behaviour.

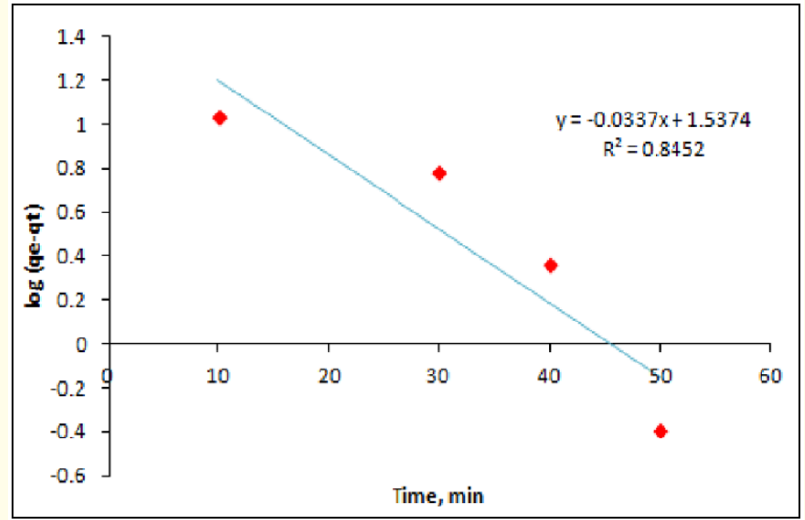

Figure 9: Pseudo-first-order reaction of adsorption (CV onto biomass).

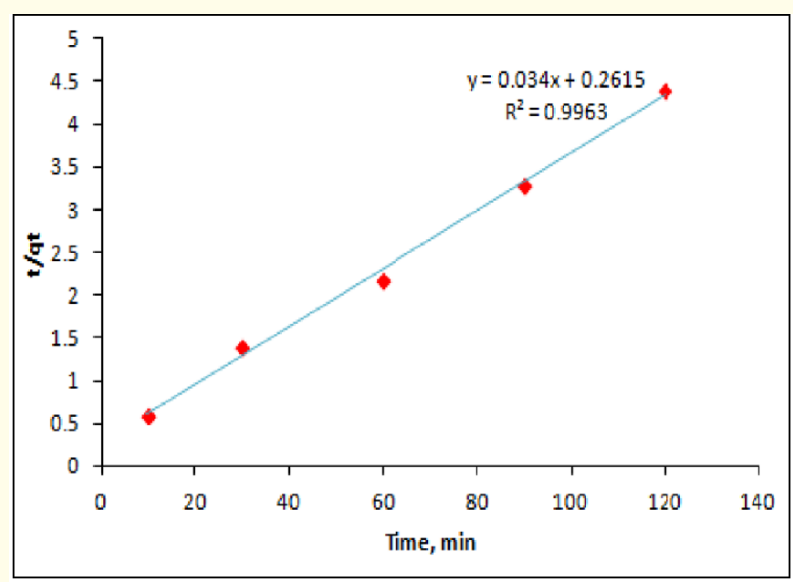

Figure 10: Pseudo-second-order reaction of adsorption (CV onto biomass).

\begin{tabular}{|c|c|c|c|c|c|}
\hline \multicolumn{7}{|c|}{ Kinetic constants } \\
\hline \multicolumn{3}{|c|}{ First-pseudo-order } & \multicolumn{3}{c|}{ Second-pseudo-order } \\
\hline $\mathrm{q}_{\mathrm{e}}$ & $\mathrm{K}_{1}$ & $\left(\mathrm{r}_{1}\right)^{2}$ & $\mathrm{q}_{\mathrm{e}}$ & $\mathrm{K}_{2}$ & $\left(\mathrm{r}_{2}\right)^{2}$ \\
\hline 29 & 0.0776 & 0.996 & 34 & 0.0044 & 0.845 \\
\hline
\end{tabular}

Table 3: Kinetic constants for the adsorption of CV onto biomass algae

Thermodynamic studies

Themperature effect on the adsorption process is another significant parameter that shows whether the adsorption nature is an exothermic or endothermic system and changes the adsorption capacity of the adsorbent [3,31-33]. A temperature study also hepls in understanding thermodynamic parameters such as free energy $\left(\Delta \mathrm{G}_{0}\right)$, enthalpy $\left(\Delta \mathrm{H}_{\mathrm{o}}\right)$, and entropy $\left(\Delta \mathrm{S}_{0}\right)$ [32]. These parameters were calculated using the following equations $[30,31]$.

$\Delta \mathrm{G}_{\mathrm{o}}=-\mathrm{RT} \ln \mathrm{Kc}$

$\mathrm{Kc}=\mathrm{q}_{\mathrm{e}} / \mathrm{C}_{\mathrm{e}}$

Also,

$\Delta \mathrm{G}_{\mathrm{o}}=\Delta \mathrm{H}_{\mathrm{o}}-\mathrm{T} \Delta \mathrm{S}_{\mathrm{o}}$

$\ln K c=\left(\Delta \mathrm{S}_{0} / \mathrm{R}\right)-\left(\Delta \mathrm{H}_{0} / \mathrm{RT}\right)$

where $\mathrm{q}_{\mathrm{e}}$ represents the amount of $\mathrm{CV}$ adsorbed onto biomass algae at equilibrium ( $\mathrm{mg} / \mathrm{l}), \mathrm{R}$ is the gas constant $(8.314 \mathrm{~J} / \mathrm{mol} \mathrm{k})$, and $\mathrm{C}_{\mathrm{e}}$ is the equilibrium concentration of $\mathrm{CV}$ in the solution $(\mathrm{mg} / \mathrm{l})$.

The effect of temperature on the adsorption efficiency were performed in the range of (293K $-328 \mathrm{~K})$. Besides, the initail cancentration of CV was maintained at $70 \mathrm{mg} / \mathrm{l}$ and all other conditions such as $\mathrm{pH}$, adsorption time, adsorbent mass, speed of stirring, working solution were kept constant. Results of temperature study is showed in figure 11. From the figure it can be seen that the percentage removal of $\mathrm{CV}$ dye increasses rapidly with an increase in temperature from 293 to $328 \mathrm{~K}$. This may be because of a rise in the mobility of adsorbate and a rise in the number of active sites for the adsorption with rising temperature [31,32]. In addition, it might be because of the rise in chemical interaction between the adsorbate and surface functionalities of the adsorbent $[32,34,35]$. Further rise in temperature reduces the swelling effect thus enabling the lage dye molecule to penetrate further [31]. This improves the diffusion rate of the adsorbate molecules across the external boundary layer and in the internal pores of the adsorbent as a result of the viscosity decreases of the solution [32,34].

On the other hand, thermodynamic parameters for CV adsorption were evaluated using equations (11-14). The values of enthalpy and entropy were determined from the slope and entercept of the plot of (ln Kc) versus $(1 / \mathrm{T})$ as shown in figure 12 . Table 4 illustrates the thermodynamic parameters for the removal of $\mathrm{CV}$ by magroalgae biomass. The obtained value of $\Delta \mathrm{H}^{\circ}(53.12 \mathrm{KJ} / \mathrm{mol})$ 
indicates that the adsorption process is an endothermic reaction. The spontaneous nature of adsorption appears due to negative value of $\Delta \mathrm{G}^{\circ}(-7.98 \mathrm{KJ} / \mathrm{mol})$. This confirms affinity of macro algae adsorbent for the adsorbate CV dye [30,31]. Similar trend was observed by Singh and Kaur, (2013) when they used rice straw for the removal of malachite green (MG) from its aqueous solutions [36].

\begin{tabular}{|c|c|c|c|}
\hline $\mathrm{T}, \mathbf{K}$ & $\Delta G^{\circ}(\mathrm{kJ} / \mathrm{mol})$ & $\Delta \mathrm{H}^{\circ}(\mathrm{kJ} / \mathrm{mol})$ & $\Delta S^{\circ}(\mathrm{J} / \mathrm{mol} \mathrm{K})$ \\
\hline 293 & -2.38 & \multirow[t]{5}{*}{53.12} & \multirow[t]{5}{*}{188.1} \\
\hline 303 & -3.52 & & \\
\hline 313 & -5.26 & & \\
\hline 323 & -7.98 & & \\
\hline 328 & -8.73 & & \\
\hline
\end{tabular}

Table 4: Thermodynamic parameters of macro algae biomass.

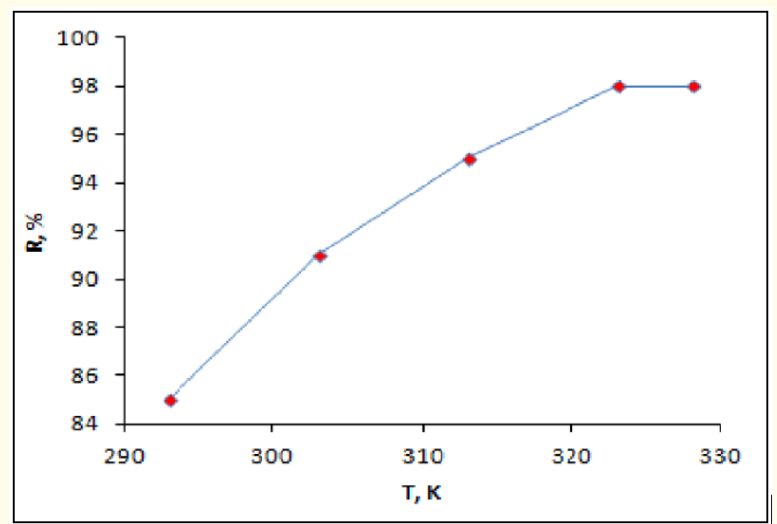

Figure 11: Effect of temperature on the percentage removal of CV onto biomass.

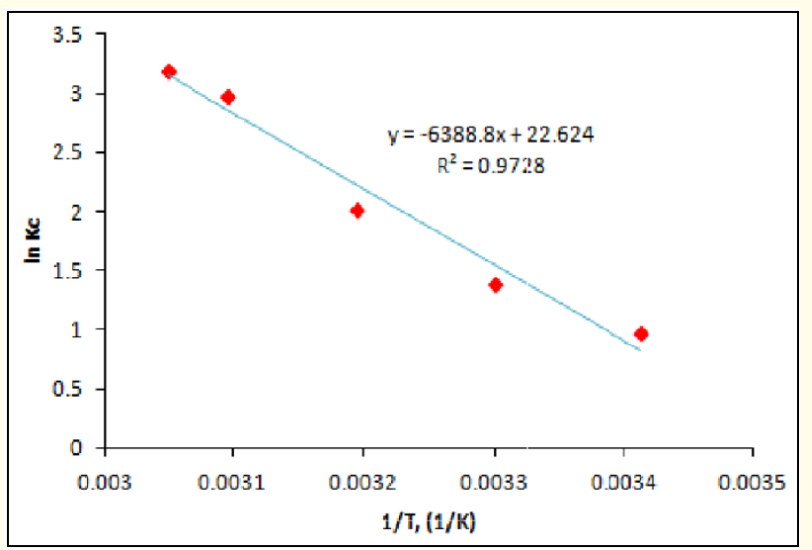

Figure 12: Van't Hoff plot for the removal of CV onto biomass.

\section{Conclusion}

In this study, macro algae biomass shows a good example of natural biosorbents for the removal of crystal violet from aqueous solution. The optimum adsorption parameters were found to be ( $0.25 \mathrm{~g}$ of adsorbent mass, contact time of $90 \mathrm{~min}$, and solution temperature of $323 \mathrm{~K}$ ). Adsorption of $\mathrm{CV}$ dye was $\mathrm{pH}$ dependent and the maximum percentag removal was attained at $\mathrm{pH}$ value of 6.5. Equilibrium data were fitted well with the Langmuir isotherm model combared to the Freundlich model. The kinetics analysis revealed that the pseudo-second-order model was a better fit for the experimental data than the pseudo-first order. The thermodynamic study demonstrates the spontaneous and endothermic nature of adsorption system. This study Also observed that the algae biomass could be widely used in the agriculture and environment cleaning purpose of toxic dyes from the industrial wastes polluting water in lakes and rivers. Further investigation about characterization of the adsorbent (including physical and chemical properties) are still necessary and recommended to support this study.

\section{Bibliography}

1. Gupta VK and Ali I. "Environmental Water Advances in Treatment, Remediation and Recycling” (2013).

2. Ariffin N., et al. "Review on Adsorption of Heavy Metal in Wastewater by Using Geopolymer". MATEC Web of Conferences 97.01023 (2017).

3. Yagub MT., et al. "Dye and Its Removal from Aqueous Solution by Adsorption: A Review". Advances in Colloid and Interface Science 209 (2014): 172-184.

4. Dawood S and Sen TK. "Review on Dye Removal from Its Aqueous Solution into Alternative Cost Effective and Non-Conventional Adsorbents". Journal of Chemical and Process Engineering 1 (2014): 104.

5. Foo KY and Hameed BH. "An Overview of Dye Removal Via Activated Carbon Adsorption Process". Desalination and Water Treatment 19 (2010): 255-274.

6. Adegoke KA and Bello OS. "Dye Sequestration Using Agricultural Wastes as Adsorbents". Water Resources and Industry 12 (2015): 8-24.

7. http://dx.doi.org/10.5772/53659 (2019). 
8. Ogugbue C and Sawidis T. "Bioremediation and Detoxification of Synthetic Wastewater Containing Triarylmethane Dyes by Aeromonas hydrophila Isolated from Industrial Effluent". Biotechnology Research International (2011).

9. Mohammed MA., et al. "Removal of Methylene Blue Using Low Cost Adsorbent: A Review”. Research Journal of Chemistry Sciences 4.1 (2014): 91-102.

10. Wee ST. "Removal of Dye by Adsorption: A Review". International Journal of Applied Engineering Research 11.4 (2016): 2675-2679.

11. Gisi SD., et al. "Characteristics and Adsorption Capacities of Low-Cost Sorbents for Wastewater Treatment: A Review". Sustainable Materials and Technologies 9 (2016): 10-40.

12. Sulyman M., et al. "Low-cost Adsorbents Derived from Agricultural By-products/Wastes for Enhancing Contaminant Uptakes from Wastewater: A Review". Polish Journal of Environmental Studies 26.2 (2017): 1-32.

13. Arumugam N., et al. "Treatment of Wastewater Using Seaweed: A Review". International Journal of Environmental Research and Public Health 15 (2018): 2851.

14. Gupta NK., et al. "Biosorption-an Alternative Method for Nuclear Waste Management: A Critical Review". Journal of Environmental Chemical Engineering 6 (2018): 2159-2175.

15. Gupta NK., et al. "Biosorption- A Green Method for the Preconcentration of Rare Earth Elements (REEs) from Waste Solutions A Review". Journal of Molecular Liquids 274 (2019): 148164.

16. Al-Azabi K., et al. "Equilibrium, Isotherm Studies of Dye Adsorption onto Orange Pell Powder". Chemistry Research Journal 3.1 (2018): 45-59.

17. Sugumaran P., et al. "Production and Characterization of Activated Carbon from Banana Empty Fruit Bunch and Delonix regia Fruit Pod". Journal of Sustainable Energy and Environment 3 (2012)125-132.

18. Lafi R., et al. "Coffee Waste as Potential Adsorbent for the Removal of Basic Dyes from Aqueous Solution". Korean Journal of Chemical Engineering 31.12 (2014): 2198-2206.
19. Hu Y., et al. "Application of Wasted Oolong Tea as a Biosorbent for the Adsorption of Methylene Blue". Journal of Chemistry (2019).

20. Isiuku BO., et al. "Adsorption Performance of Acid-Activated Carbon Derived from Gmelina Arborea in Batch Removal of Methyl Violet from Aqueous Solution". Journal of Chemical Society of Nigeria 44.1 (2019): 011-021.

21. Sulyman M., et al. "New Approach for In-House Treatment of Colored Wastewater Using Olive-Waste Cake as an Alternative Adsorbent". IOSR Journal of Environmental Science, Toxicology and Food Technology 10.12 (2016): 19-31.

22. Hanan Omar., et al. "Bioremoval of Toxic Dye by Using Different Marine Macroalgae". Turkish Journal of Botany (2018) 42: 15-27.

23. Etim UJ., et al. "Coconut Coir Dust as a Low Cost Adsorbent for the Removal of Cationic Dye From Aqueous Solution". Journal of Saudi Chemical Society 20.1 (2016): S67-S76.

24. Langmuir I. "Adsorption of Gases on Plain Surfaces of Glass Mica Platinum". Journal of the American Chemical Society 40 (1918):1361-1403.

25. Freundlich $\mathrm{H}$ and Heller W. "The Adsorption of Cis- and Trans azobenzene". Journal of the American Chemical Society 61 (1939) 2228-2230.

26. Lagergen S. "On the Theory of So-Called Adsorption of Dissolved Substances". Handlingar 24 (1898):1-39.

27. Ho YS and McKay G. "Pseudo-second Order Model for Adsorption Processes". Process Biochemistry 34 (1999): 451-465.

28. Wang JS., et al. "Biosorption of Uranium (VI) by Immobilized Aspergillus Fumigatus Beads". Journal of Environmental Radioactivity 101 (2010): 504-508.

29. Aljeboree AM., et al. "Kinetics and Equilibrium Study for the Adsorption of Textile Dyes on Coconut Shell Activated Carbon". Arabian Journal of Chemistry 10 (2017): S3381-S3393.

30. Sartape AS., et al. "Removal of Malachite Green Dye from Aqueous Solution with Adsorption Technique Using Limonia Acidissima (Wood Apple) Shell as Low-Cost Adsorbent". Arabian Journal of Chemistry 10 (2017): S3229-S3238. 
31. Pathania D., et al. "Removal of Methylene Blue by Adsorption onto Activated Carbon Developed from Ficus Carica Bast". Arabian Journal of Chemistry 10 (2017): S1445-S1451.

32. Khatoon H. and Rai J. P. "Agricultural Waste Materials as Biosorbents for the Removal of Havy Metals and Synthetic Dyes: A Review". Octa Journal of Environmental Research 4.3 (2016): 208-229.

33. Kamsonlian S. et al. "Biosorptive Behaviour of Mango Leaf Powder and Rice Husk for Arsenic (III) from Aqueous Solutions". International Journal of Environmental Science and Technology 9 (2012): 565-578.

34. Kumar R. and Ahmad R. "Biosorption of Hazardous Crystal Violet Dye from Aqueous Solution onto Treated Ginger Waste (TGW)". Desalination 265 (2011): 112-118.

35. Patil S., et al. "Kinetics of Adsorption of Crystal Violet from Aqueous Solution Using Different Natural Materials". International Journal of Environmental Sciences 1.6 (2011): 11161134.

36. Singh J. and Kaur G. "Freundlich, Langmuir Adsorption Isotherms and Kinetics for the Removal of Malachite Green from Aqueous Solutions Using Agricultural Waste Rice Straw". International Journal of Environmental Sciences 4.3 (2013).

\section{Volume 3 Issue 7 July 2019}

(C) All rights are reserved by Mohamed Sulyman., et al. 